\title{
The Development a New Device to Measure of Audial and Visual Reaction Time in Hand and Foot (Validity and Reliability Study)
}

\author{
Ozturk AGIRBAS ${ }^{1}$, Eser AGGON ${ }^{2} \&$ Recep $\mathrm{OZ}^{3}$ \\ ${ }^{1}$ School of Physical Education and Sports, Bayburt University, Bayburt, Turkey \\ ${ }^{2}$ School of Physical Education and Sport, Erzincan University, Erzincan, Turkey \\ ${ }^{3}$ Faculty of Education, Department of Computer Education and Instructional Technology, Erzincan University, \\ Erzincan, Turkey \\ Correspondence: Ozturk AGIRBAS, School of Physical Education and Sports, Bayburt University, Bayburt, \\ Turkey.
}

Received: November 18, 2018

doi:10.5539/ies.v12n4p165

\author{
Accepted: December 30, $2018 \quad$ Online Published: March 20, 2019 \\ URL: https://doi.org/10.5539/ies.v12n4p165
}

\begin{abstract}
The determining the reaction time is a widely used as an indicator in sportive performance and field of exercise physiology. The purpose of this study is to develop a new reaction times device (NRTD) to determine both hand and foot visual and auditory reaction times, which is practical and economical. In the developed system to be obtained are kept in a database which is all necessary the intervals between stimuli for the reaction variable and all records. The system consists of software loaded on a computer and buttons specially prepared for hands and feet. The buttons are designed for precise measurement. The software of the program is written with Visual Basic program. The program can be recorded different features separately for each subject in the database except the reaction times. Also the system metrics can be presentedas a report to the user. While comparisons were made with the Newtest 1000 reaction device to determine the validity of the tool we developed, repeated measurements were made on the same group each week to determine its reliability. Measurements were carried out on 52 male students studying in Erzincan University's School of Physical Education and Sports. The resulting data were examined in SPSS 22.0 statistical package program for Windows. Independent Student T-test was used to compare two devices; Paired Sample T-test was used to compare repeated measurements of NRTD. No significant difference was detected statistically between neither right nor left-hand visual reaction times conducted with the device we have developed and Newtest 1000, or the repeated measurement results which were conducted each week with NRTD. It was concluded that NRTD is valid and reliable to measure reaction time and is an ideal measurement tool to measure both hand and foot reaction times.
\end{abstract}

Keywords: reaction time, hand and foot reaction time, visual and audial reaction time

\section{Introduction}

Reaction time is the time that elapses from the start time of the stimulus and the time interval at which the response begins (Bompa, 1998; Tamer, 2000; Carreiro et al., 2003; Gunay, Tamer \& Cicioglu, 2013). Reaction time can be examined in different ways. While Bhabhor et al. (2013) separates reaction time to sections as detection time, decision time and motor time; Ziyagil et al. (1994) stated that reaction time is physiologically composed of 5 parts. These are; seeing the warning on the receptor level, transmitting the warning to the central nervous system, transferring the warning via nerves and creating the effector signal, moving the signal to muscles through the central nervous system and stimulating the muscle for the mechanical work to be performed (Ziyagil, Tamer \& Zorba, 1994; Bhabhor et al., 20135,6).

Reaction time was usually studied in two categories, which are simple and complex (elective) (Oxendine, 1984). Simple Reaction Time (SRT) corresponds the speed of the response given by the person without requiring any integration or decision-making process. Simple reaction time is the time that elapses between a single given warning with a single given answer (Colakoglu, Tiryaki \& Moral1, 1993, Spirduso, Francis \& MacRae, 2005). Selective Reaction Time corresponds to situations where there are two or more possible stimuli that require different responses, and where these stimuli are considered to be a useful variable to demonstrate the speed of decision-making processes (Nougier et al., 1992). In short, while the incoming warning is singular and specific in 
simple reaction time, there is more than one stimulus in selective reaction time and it's not certain which one will come.

Reaction time is under the influence of many factors. These factors may have a positive or negative effect. While factors such as inadequate training, fatigue, carelessness and inadequate fighting spirit have negative effects (Akgun, 1994); factors such as attention, propulsion, heating, reaction speed practices have positive effects (Gunduz, 1998). From here, the result can be reached that there is a strong relationship between exercise and reaction time. Davranche et al. (2006) stated that exercise accelerates the reaction time by increasing stimulation (Davranche, Audiffren, \& Denjean, 2006). To measure reaction time, which is also an important concept for sports sciences, other than quite simple answers such as pressing a button or letting a button go, measurement can also be performed with various shapes and methods of joints (Colakoglu, Tiryaki, \& Moral1, 1993). Today, with the development of computer technology, many more sensitive programs/tools were developed, which are designed to measure reaction time. Some of these tools are simple software that can be accessed on the internet but are questionable in terms of reliability, while others are highly reliable tools both in terms of software and hardware maintenance. However, it's almost impossible to access these tools especially due to economic reasons.

The two most important properties required in a measuring tool are validity and reliability. Validity is to measure the property to be measured accurately and correctly (Ercan \& Kan, 2004). Reliability is the consistency between measurement values obtained with a measurement tool in repeated measurements under the same conditions at different times (Oncu, 1994). The aim of this study is to develop a practical, economic and accessible measurement software system for determining both hand and feet reaction times according to visual, audio or mixed stimuli which are commonly used especially in the exercise physiology field, and to perform studies for this software's validity and reliability.

\section{Method}

The Method section describes in detail how the study was conducted, including conceptual and operational definitions of the variables used in the study, Different types of studies will rely on different methodologies; however, a complete description of the methods used enables the reader to evaluate the appropriateness of your methods and the reliability and the validity of your results, It also permits experienced investigators to replicate the study, If your manuscript is an update of an ongoing or earlier study and the method has been published in detail elsewhere, you may refer the reader to that source and simply give a brief synopsis of the method in this section.

\subsection{Simple Reaction Time Measuring System}

Reaction time measurements are generally made in the literature with LaFayette or New Test 2000 devices. Apart from these, researchers developed their own devices (Kosinski \& Cummings, 1999). In this study, the physical parts of the device were first brought together and then they were used with computer software. The system consists of three parts. These are computer, simple reaction time software and measuring instrument.

1) Computer: For the program to work, the minimum system features of the computer are these; i3 (Intel) processor, 1 GB RAM, 1 GB Hard Drive, .Net Framework 4.5, USB 2.0 or 3.0 port.

2) Simple Reaction Time Software: The computer program to be used in the measurement process was created with the C \# (C Sharp) program in the Visual Studio 2015 program by Microsoft. The program was designed using the MetroFramework interface. The program is quite user-friendly and suitable for touch screens. The opening screen is shown in Figure 1. From this screen, the user can easily switch to Add Lead, Add Measurement and Reporting screens. 


\section{SIMPLE REACTION TIME}

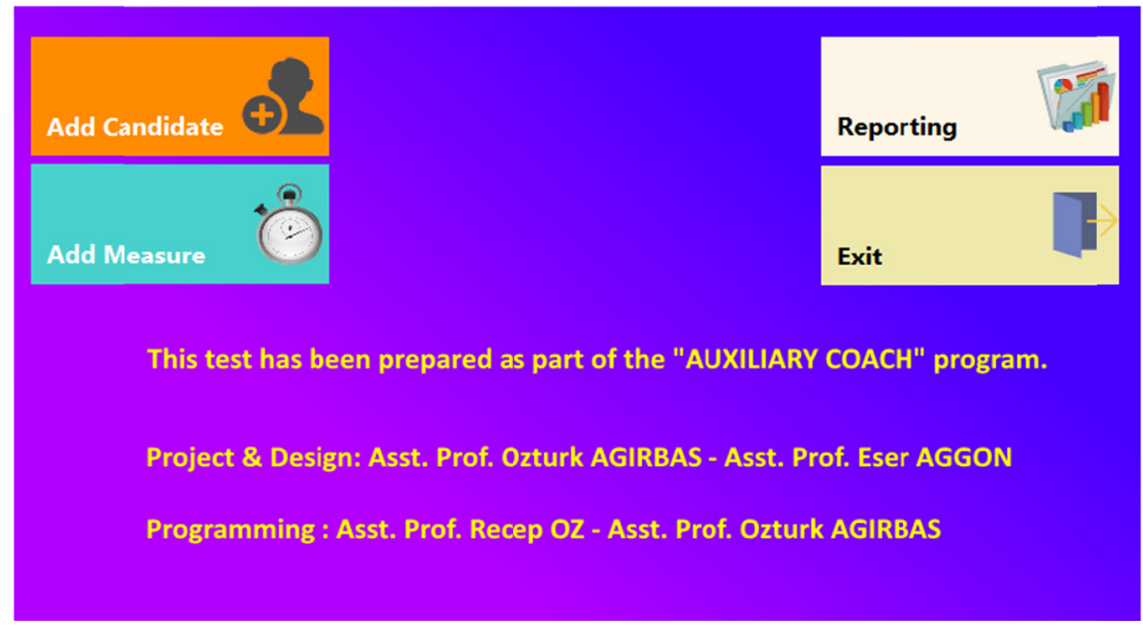

Figure 1. Opening screen

When the Add Candidate button is pressed, the display changes to the subway as in Figure 2.

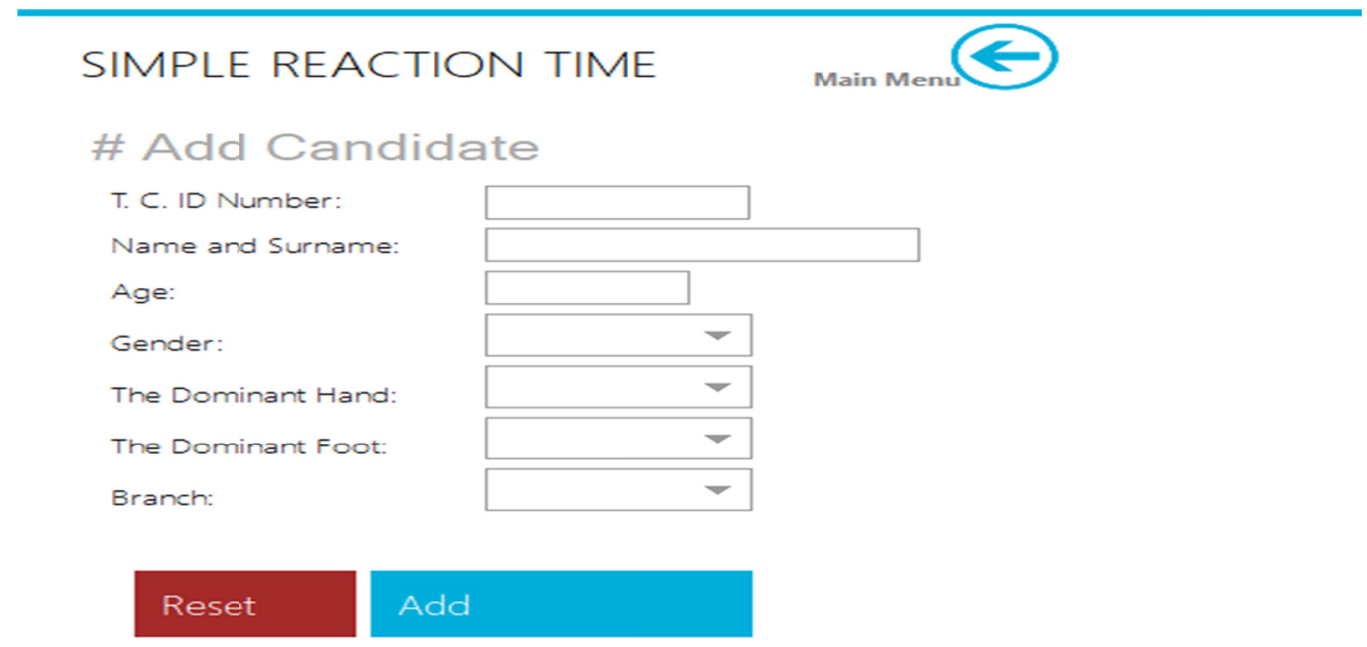

Figure 2. Add candidate screen

In this screen, the name of the candidate, T.C. ID Number, age, gender, dominant hand, dominant foot and branch information are recorded in the database. To return to the Main Menu, click the Main Menu link at the top. 


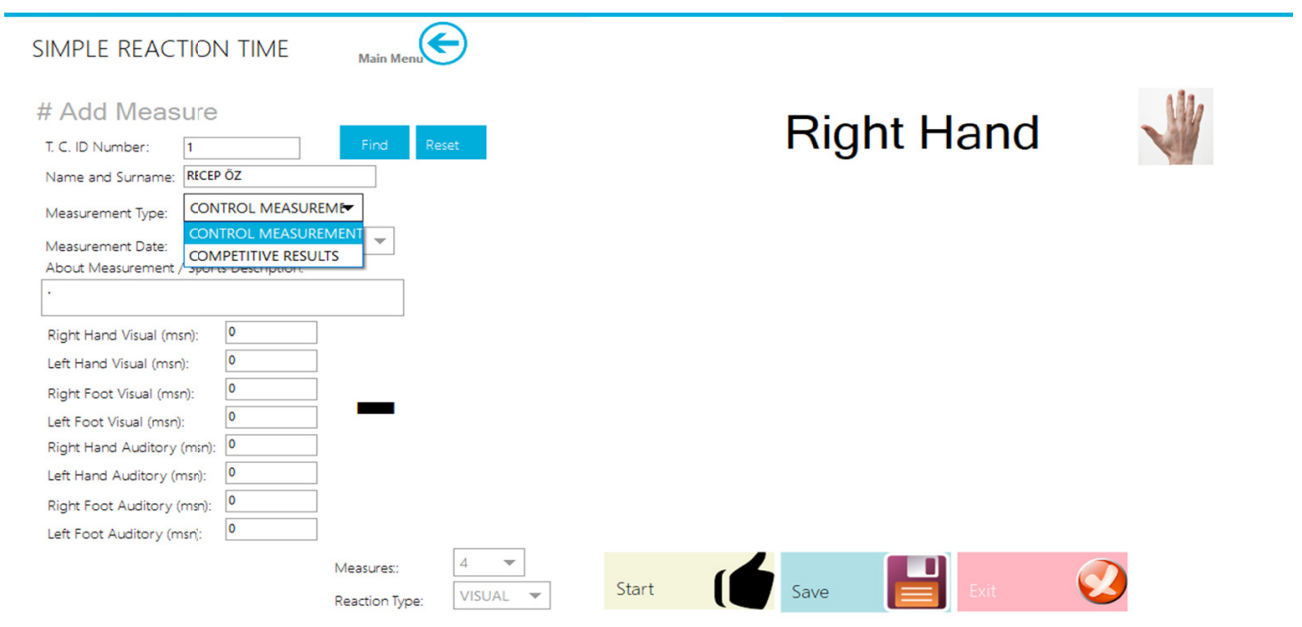

Figure 3. Add measurement screen

In this section, enter T.C. ID Number of the Candidate and press the Find button. If registered, the name and surname of the candidate come automatically. The measurement type is then selected from the list. The date of the day in the measurement date section is available. If desired, the date can be changed easily. Information about the measurement and the athlete can be written in the description section. Select the number of measurements from the drop-down list. The reaction type can be selected visually and audibly. When clicked on the start button, the system counts backwards from 3 and makes the window on the screen red to be completely random for the right hand. When the display is red, the timer continues to run, until in milliseconds the button on the device is clicked. When the button on the device is clicked, it stops the counting process and assigns the current value to a variable. This operation continues for the right hand until the number of measurements. Then the best and the worst value is removed, the arithmetic average is taken and this value is written to the relevant field. When click on Add Measurement button, the screen in Figure 3 is active. Then, the process starts from the beginning for the left hand, right foot and the left foot respectively and the values are automatically written to the relevant places. When the measurement process is finished, it makes a warning with the message and the next measurement is started. The auditory measurement is similar (Figure 4). When clicked on start button, system starts counting backwards from 3 and playing an audio file completely for right hand. When this audio file starts to play, the timer continues to run, until in milliseconds the button on the device is clicked. When the button on the device is clicked, it stops the counting process and assigns the current value to a variable. This operation continues for the right hand until the number of measurements. Then the best and the worst value is removed, the arithmetic average is taken and this value is written to the relevant field.

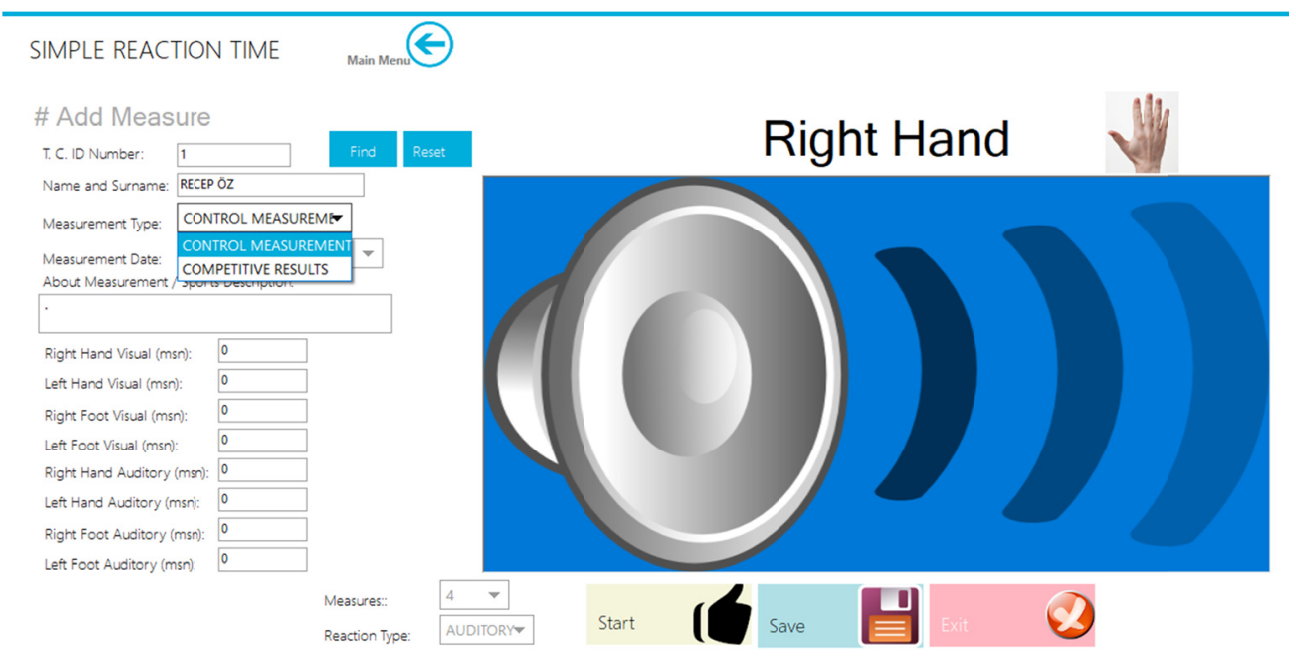

Figure 4. Auditory reaction screen 
After the visual, auditory or audiovisual measurements are finished, the data is saved in the database by pressing the save button (Figure 5).

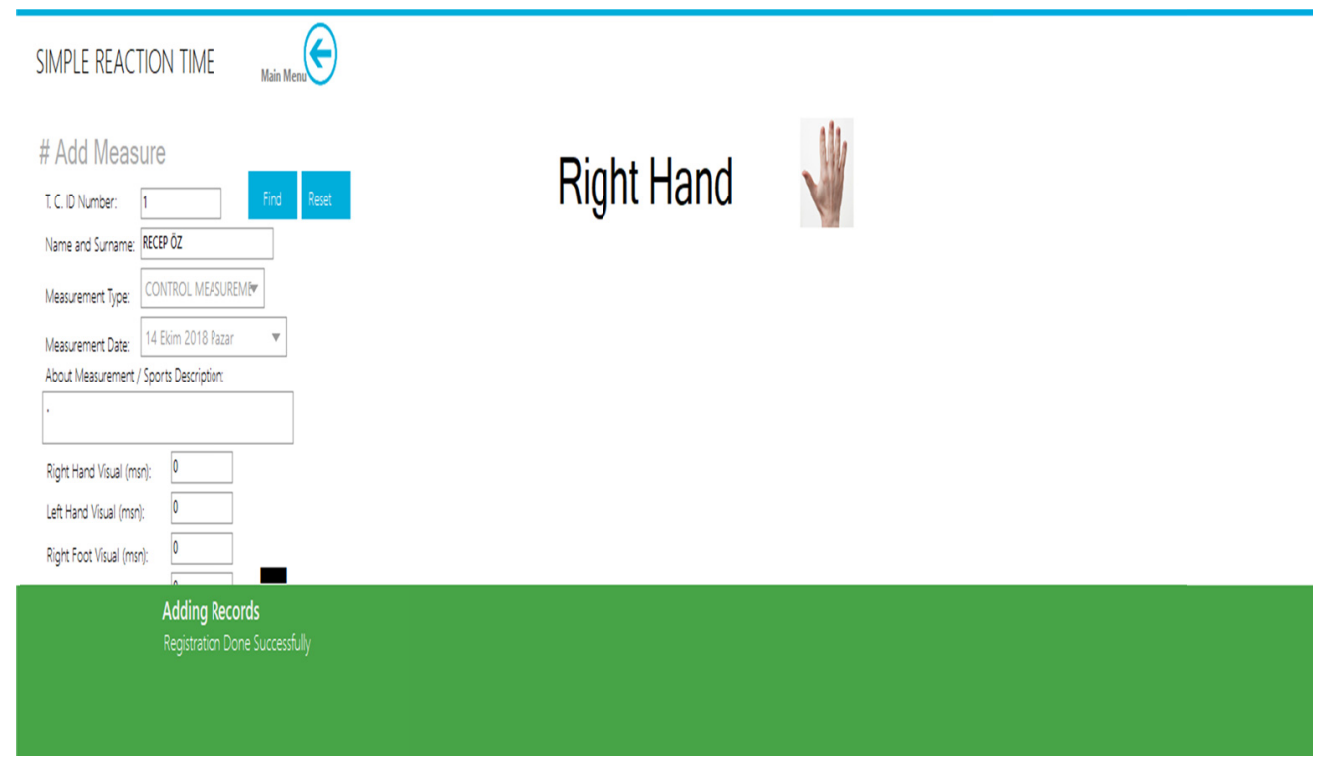

Figure 5. Data saving screen

All records made up to now with the Reporting button in the main menu are listed according to the branch or name (Figure 6).

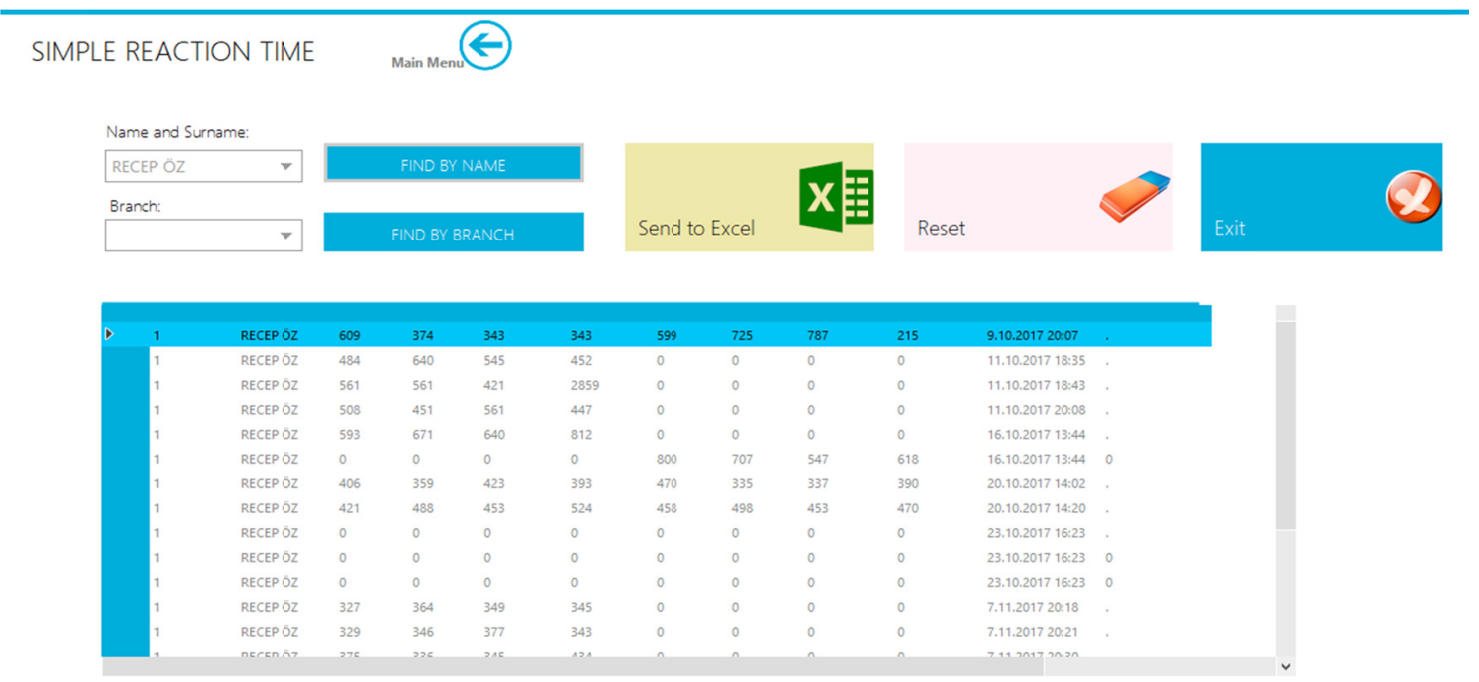

Figure 6. Data reporting screen

If desired, this data can be easily sent to Microsoft Excel (Figure 7). Information transferred to Excel can be analyzed easily. 


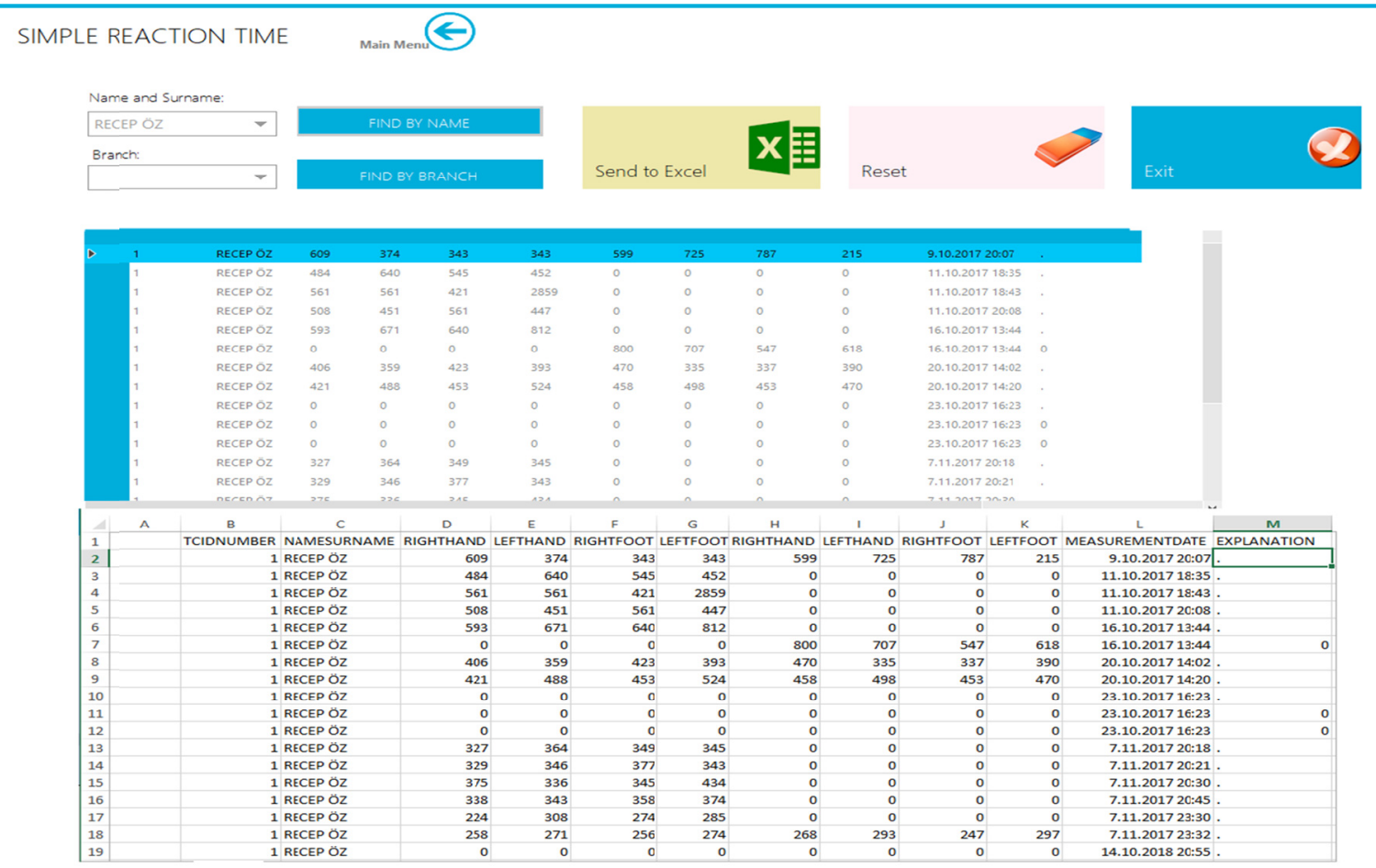

Figure 7. Data Export Screen

3) Measuring Instrument:

The device consists of two parts. There are 2 buttons for Right and Left Hand in the upper compartment and 2 buttons for Right and Left in the lower section. The candidate sits in front of the device with the help of a chair. The hands and feet are held in close proximity to the buttons and are pressed in sequence when the program runs. The case is completely aluminum construction. The buttons are mounted on the main body from durable material. The device is connected to the computer via USB port.

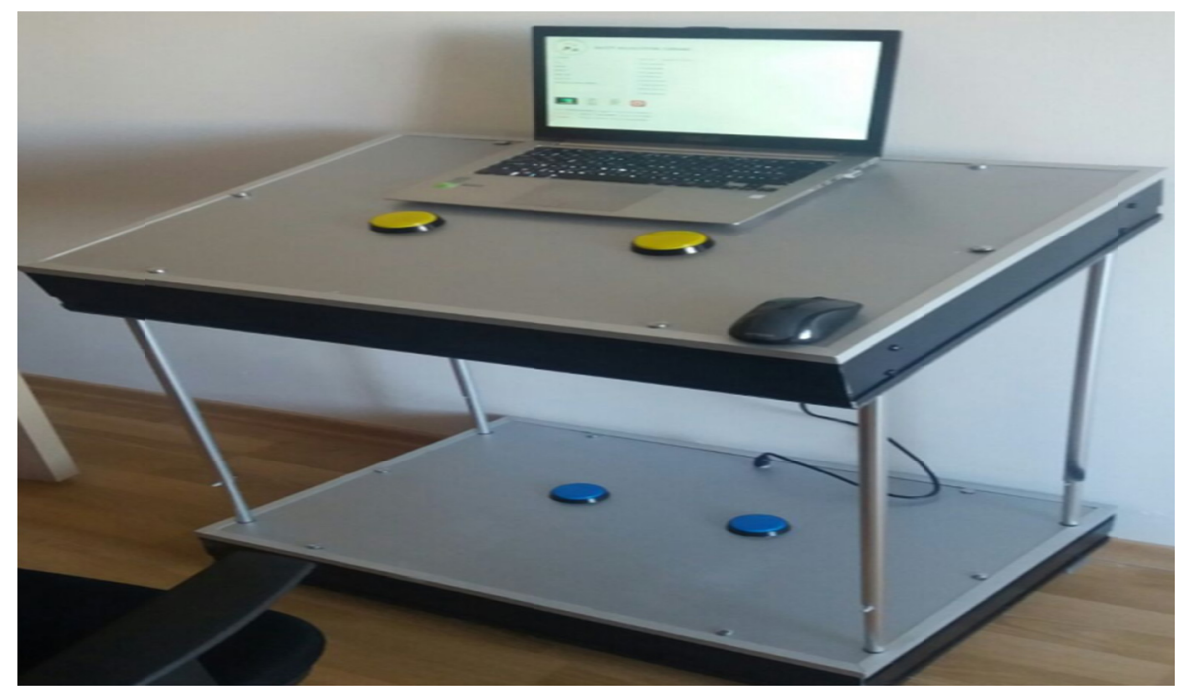

Figure 8. Simple reaction time measuring instrument

\subsection{Research Group and Test Measurements}

Reaction times were measured with each of the two devices on 52 male students who study in Erzincan University's School of Physical Education and Sports. Following the completion of reaction time software and button systems, the system's controls were performed through test measurements. It was compared with the 
Newtest 1000 reaction device to determine the validity of the measurement tool. It was repeatedly measured with the same group each week to determine the reliability of the measurement tool.

\subsection{Statistical Analysis}

The resulting data were examined in SPSS 22.0 statistical package program for Windows. First, normality analysis was performed and the distribution was found to be normal. In order to ascertain the validity of the the reaction time measurement tool developed, measurement results of the same group which were performed with Newtest 1000 reaction time device were compared with the independent Student T-test. In order to determine the reliability of the reaction time measurement tool, repeated measurements were made to the same group each week and the results were compared with the Paired Sample T-test.

\section{Results}

Table 1 shows the comparison of the measurement results made on the same group with the Newtest 1000 reaction time device to determine the validity of NRTD.

Table 1. Comparison of the left and right-hand visual reaction times of left with NRTD and Newtest 1000 with the Independent Student T-test

\begin{tabular}{lllllll}
\hline Reaction Type & Device & $\mathrm{N}$ & $\mathrm{X}$ & $\mathrm{ss}$ & $\mathrm{t}$ & $\mathrm{p}$ \\
\hline \multirow{2}{*}{ Right Hand- Visual Reaction Time (msec) } & NRTD & 52 & 229.23 & 21.21 & \multirow{2}{*}{1.131} & \multirow{2}{*}{.27} \\
\cline { 2 - 5 } & Newtest 1000 & 52 & 218.84 & 27.32 & & \\
\hline \multirow{2}{*}{ Left Hand- Visual Reaction Time (msec) } & NRTD & 52 & 235.15 & 26.84 & \multirow{2}{*}{1.175} & \multirow{2}{*}{.25} \\
\cline { 2 - 5 } & Newtest 1000 & 52 & 221.08 & 34.28 & & \\
\hline
\end{tabular}

NRTD: New Reaciton Time Device, msec: millisecond.

When Table 1 is examined, it is seen that there is no statistically significant difference between right and left-hand visual reaction times performed with NRTD and Newtest 1000 .

Comparison of weekly repeated measurement results to detect the NRTD reliability was given in Table 2 .

Table 2. Comparison of the left and right hands visual reaction times which were repeatedly performed with NRTD with Paired Sample T-test

\begin{tabular}{lllllll}
\hline Reaction Type & Measurement Time & $\mathrm{N}$ & $\mathrm{X}$ & $\mathrm{ss}$ & $\mathrm{t}$ & $\mathrm{p}$ \\
\hline \multirow{2}{*}{ Right Hand- Visual Reaction Time (msec) } & Pre & 52 & 229.23 & 21.21 & \multirow{2}{*}{1.449} & \multirow{2}{*}{.18} \\
\cline { 2 - 5 } & Post (After one week) & 52 & 227.16 & 22.63 & & \\
\hline \multirow{2}{*}{ Left Hand- Visual Reaction Time (msec) } & Pre & 52 & 235.15 & 26.84 & \multirow{2}{*}{1.483} & \multirow{2}{*}{.17} \\
\cline { 2 - 5 } & Post (After one week) & 52 & 233.81 & 27.47 & & \\
\hline
\end{tabular}

When Table 2 is examined, it is seen that there is no statistically significant difference between NRTD and the results of weekly repeated measurements.

\section{Conclusion and Suggestions}

As a result of the research:

- It was determined that there is no difference between the reaction time measurement device we have developed and the Newtest 1000 device in terms of left and right-hand visual reaction time values (Table 1). This result suggests that the device is valid to measure reaction time.

- It was determined that there was no statistically significant difference between the reaction time measurement device we have developed and weekly repeated measurement results (Table 2). This result indicates that the device is reliable.

It is considered that the system we ha ve developed will fulfill needs of many researchers, due to being new and useful for measuring foot reaction time especially. It is suggested that its production and use should be popularized, due to the consideration that it will be an economic and accessible measurement tool.

\section{Acknowledgments}

$\mathrm{OA}$ and EA planned and designed the project and wrote the paper, RO programmed the new reaction time device. 
The authors declare that there is no conflict of interests regarding the publication of this paper.

The study was financed by Bayburt University Scientific Research Projects Coordination Unit (Project No: 2016/01-14) and it was published as Oral Presentation in 15. International Sport Science Congress (15-18 November 2017, Antalya, TURKEY).

We would like to thank to Bayburt University Scientific Research Projects Coordination Unit and all the participants that supported the research.

\section{References}

Akgun, N. (1994), Egzersiz Fizyolojisi, 2. Cilt, Ege Universitesi Basımevi, İzmir (pp. 74 -80).

Bhabhor, M. K., Vidja, K., Bhanderi, P., Dodhia, S., Kathrotia, R., \& Joshi, V. (2013). Short Communication A comparative study of visual reaction time in table tennis players and healthy controls. Indian J Physiol Pharmacol, 57(4). 439-442

Bompa T. O. (1998). Antrenman Kuramı ve Yontemi (Cev: Keskin I., Taner, AB.). Bagırgan Yayınevi, Ankara (p. 433).

Carreiro, L. R. R., Haddad Jr, H., \& Baldo, M. V. C. (2003). The modulation of simple reaction time by the spatial probability of a visual stimulus. Brazilian Journal of Medical and Biological Research, 36(7), 907-911. https://doi.org/10.1590/S0100-879X2003000700011

Colakoglu, M., Tiryaki, S., \& Moralı, S. (1993). Konsantrasyon Calısmalarının Reaksiyon Zamanı Uzerine Etkisi. Spor Bilimleri Dergisi, 4(4), 32-47.

Davranche, K., Audiffren, M., \& Denjean, A. (2006). A distributional analysis of the effect of physical exercise on a choice reaction time task. Journal of Sports Sciences, 24(3), 323-329. https://doi.org/10.1080/02640410500132165

Ercan, İ., \& Kan, İ. (2004). Olceklerde guvenirlik ve gecerlik. Uludag Universitesi Tup Fakultesi Dergisi, 30(3), 211-216.

Gunay, M., Tamer, K., \& Cicioglu, İ. (2013). Spor Fizyolojisi ve Performans Olcumu, Gazi Kitapevi. Ankara.

Gunduz, N. (1998). Antrenman Bilgisi, Saray Medikal Yaylncllk. Kanyılmaz Maatbası, Ankara (pp. 193-194).

Kosinski, B., \& Cummings, J. (1999). The scientific method: An introduction using reaction time. Tested studies for laboratory teaching, 20, 63-84.

Nougier, V., Azemar, G., Stein, J. F., \& Ripoll, H. (1992). Covert orienting to central visual cues and sport practice relations in the development of visual attention. Journal of Experimental Child Psychology, 54(3), 315-333. https://doi.org/10.1016/0022-0965(92)90023-Y

Oncu, H. (1994). Egitimde Olcme ve Degerlendirme. Matser Basım San. Ve Tic. Ltd. Sti. Ankara.

Oxendine, J. B. (1984). Psychology of motor learning. Prentice Hall. New Jersey.

Spirduso, W. W., Francis, K. L., \& MacRae, P. G. (2005). Physical Dimensions of Aging (2nd ed., pp. 62-165). Human Kinetics. USA.

Tamer, K. (2000). Sporda Fizyolojik Fiziksel Performansın Olculmesi ve Degerlendirilmesi. 2. Baskl, Bagırgan Yayinevi, Ankara, 32, 184.

Ziyagil, M. A., Tamer, K., \& Zorba, E. (1994). Beden Egitimi ve Sporda Temel Motorik Ozelliklerinin ve Esnekligin Gelistirilmesi. Ofset Matbaacılık, Ankara.

\section{Copyrights}

Copyright for this article is retained by the author(s), with first publication rights granted to the journal.

This is an open-access article distributed under the terms and conditions of the Creative Commons Attribution license (http://creativecommons.org/licenses/by/4.0/). 